\title{
BARIATRIC SURGERY REVERSES METABOLIC RISK IN PATIENTS TREATED IN OUTPATIENT LEVEL
}

\author{
Cirurgia bariátrica reverte risco metabólico em pacientes assistidos em nível ambulatorial \\ Epifânio Feitosa da SILVA-NETO, Cecília Ma Passos VÁZQUEZ, Fabiana Melo SOARES, \\ Danielle Góes da SILVA, Márcia Ferreira Cândido de SOUZA, Kiriaque Barra Ferreira BARBOSA
}

From the Departamento de Nutrição, Universidade Federal de Sergipe, Cidade Universitária Professor José Aloísio de Campos (Department of Nutrition, Federal University of Sergipe, Professor José Aloísio de Campos University City), Aracaju, SE, Brazil.

HEADINGS - Bariatric surgery. Cardiometabolic risk. Diabetes mellitus. Hypertension. Dyslipidemia.
ABSTRACT - Background: The conventional treatment of obesity presents unsatisfactory results on weight loss and its long-term sustainability, therefore bariatric surgery has been suggested as an effective therapy, determining sustainable long-term weight loss, reversal of components of cardiometabolic risk and improved quality and life expectancy. Aim: To investigate the clinical component of the cardiometabolic risk in patients undergoing bariatric surgery assisted on outpatient basis. Methods: The sample consisted of 47 patients with ages between 18 and 60 years, $72 \%$ females. Diabetes mellitus, hypertension, and dyslipidemia were prospectively evaluated by using the Assessment of Obesity-Related Co-morbidities scale. Results: Occurred improvement in these co-morbidities within 12 months after surgery. Co-morbidities resolved were greater than those improved. Conclusion: The study revealed that the Assessment of Obesity-Related Co-morbidities is a system that can be effectively used to quantify the degree of reduction of the severity of the cardiometabolic risk in response to bariatric surgery.

\section{Correspondence:}

Kiriaque Barra Ferreira Barbosa

E-mail: kiribarra@yahoo.com

Financial source: none

Conflicts of interest: none

Received for publication: 06/08/2013

Accepted for publication: 05/12/2013

DESCRITORES - Cirurgia bariátrica. Risco cardiometabólico. Diabete melito. Hipertensão. Dislipidemia.
RESUMO - Racional: Diante dos resultados insatisfatórios do tratamento convencional da obesidade na perda ponderal e na sua sustentabilidade em longo prazo, a cirurgia bariátrica vem sendo apontada como terapêutica eficaz, determinando perda ponderal sustentável em longo prazo, reversão de componentes do risco cardiometabólico e melhora da qualidade e expectativa de vida. Objetivo: Acompanhar a evolução clínica dos componentes do risco cardiometabólico em pacientes submetidos à cirurgia bariátrica. Métodos: A amostra constituiu-se de 47 pacientes de 18 a 60 anos de idade, $72 \%$ do sexo feminino. A evolução clínica das comorbidades diabete melito, dislipidemia e hipertensão arterial, foi quantificada, procedendo-se ao cálculo de escores relativos à Avaliação das Comorbidades Relacionadas à Obesidade. Resultados: Houve redução significativa do escore médio de todas as comorbidades relacionadas à obesidade, desde a admissão até os 12 meses seguintes. Independente do momento de assistência nutricional, o contingente de pacientes que as tiveram revertidas superou aqueles apenas melhoradas. Conclusão: O estudo revelou que a Avaliação das Comorbidades Relacionadas à Obesidade é sistema efetivo para quantificar o grau de redução da gravidade do risco cardiometabólico em resposta à cirurgia bariátrica.

\section{INTRODUCTION}

$\mathrm{O}$ besity and its co-morbidities have reached alarming prevalence, becoming a public health problem worldwide, independent of gender, age and social status. From the unsatisfying results seen in conventional treatment on weight loss and its long term sustainability, bariatric surgery has been pointed out as an efficient treatment, determining sustainable weight loss, cardiometabolic risk factors (CMR) and life expectancy and quality improvements ${ }^{7,8,12}$.

Weight loss and maintenance after bariatric surgery can be understood by behavior changes that are inserted in the patient's life. The food habit change provided by the adoption of a high calorie diet associated to ingestion of high nutritional value foods and the 
beginning of a regular physical activity, are essential measurements that help the weight loss after surgery. Besides behavior factors, the Roux Y gastric by-pass surgery technique contributes, through anatomy and hormonal changes, in a significant manner, to loss and maintenance of weight with the best co-morbidities ${ }^{1,12,14}$.

Individuals submitted to bariatric surgery with nutritional assistance can achieve loss of 40 to $50 \%$ from the initial weight in a short period of time, being possible the long term maintenance ${ }^{2}$. The favorable effect of the gastric pouch reduction and the jejunal derivation in Roux $Y$ considering reversion and control of the CMR components is described in many populations ${ }^{10,5}, 9,3$.

Mohamed et al (2009) ${ }^{11}$ proposed an instrument capable of measuring, in a quantitative manner, the co-morbidities changes related to obesity after bariatric surgery, with this instrument it is possible to quantify the enhancement of revise the components of cardio metabolic risk.

Life expectation increase and mortality reduction with surgery is, partly, mediated by CMR reversion; therefore, the present study has as goal to evaluate and quantify the clinical evolution of CMR components in patients submitted to bariatric surgery by Roux $Y$ laparoscopic method, assisted in ambulatory level.

\section{METHODS}

The study is transversal, with sampling by convenience, carried out at the nutrition ambulatory of the Universidade Federal de Sergipe (CAAE $n^{\circ}$ 0281.0.107.000-11).

Data collection was taken from records and protocols, using ambulatory assistance for the patients, in a period from May to June of 2012, 47 records of patients submitted to bariatric surgery, were selected. The records that were included in the study were properly filled, presenting all data, with diagnose at the admission of the following co-morbidities associated to obesity: arterial hypertension, dyslipidemia and diabetes mellitus.

Anthropometric data referring to weight and height were checked by recommended techniques and instruments, the Body Mass Index (BMI) was calculated and the nutritional state classified, according to cutting points of the World Health Organization ${ }^{6}$.

Biochemical and clinical data related to serum and plasmatic doses of triglycerides, total cholesterol, cholesterol - HDL, cholesterol - LDL and jejunal glucose, were collected. Further systolic and diastolic arterial pressure were measured.

Clinical evaluation of the cardiometabolic risk components ( CMR) evolution was quantified, according to a proposal presented in previous study, taking scores calculus related to Obesity-Related Co-Morbidities Evaluation (ORCE). It was based in a points system which attributed scores from $0-5$, according to severity for CMR components: diabetes mellitus, dyslipidemia and systemic arterial hypertension (Figure 1). The scores were attributed to the admission time, surgery authorization and after surgery return, on the $3^{\text {rd }}, 6^{\text {th }}$ and $12^{\text {th }}$ month, approximately.

\section{Statistical analysis}

The medium $(X)$, standard deviation (SD), absolute (n) and relative (\%) frequency, were calculated. Due to sample size and variables distribution, non-parametric tests were adopted. The W-Wilcoxon test was used to compare different moments of nutritional assistance. For categorical variables the Qui-Square test was used. A $5 \%$ probability statistical significance $(p<0.05)$ was considered. Statistical analysis were carried out using the Statistical Package for the Social Science (SPSS), version 17.0 for Windows.

\begin{tabular}{|cl|}
\hline AORC score & Description \\
\hline Diabetes mellitus & \\
\hline 1 & Absence \\
\hline 2 & Glucose Intolerance \\
\hline 3 & Diabetes mellitus (diagnosed) \\
\hline 4 & Controlled with an oral anti-diabetic \\
\hline 5 & Clinical Complications \\
\hline Dyslipidemia & \\
\hline 0 & Absence \\
\hline 1 & Limit values (200-239 mg/dl) \\
\hline 2 & Conventional control (diet + physical activity) \\
\hline 3 & Single medication \\
\hline 4 & Multiple medication \\
\hline 5 & Non-controlled \\
\hline Hypertension & \\
\hline 0 & Absence \\
\hline 1 & Limit values (systolic: 130- 139 mmHg; \\
\hline 2 & dyastolic:85-89 mmHg) \\
\hline 3 & Conventional control (diet + physical activity) \\
\hline 4 & Single medication \\
\hline 5 & Multiple medication \\
\hline & Non-controlled \\
\hline
\end{tabular}

FIGURE 1 - Assessment of Obesity-Related Co-morbidities (AORC)

\section{RESULTS}

Forty-seven patients participated on this study, being $72 \%$ women (44 y). At admission the prevalence of obesity grade III was $100 \%$; at surgery and 12 months after, a percentage reduction was seen, for $80,9 \%$ and $34.2 \%$, respectively (Table 1 ). 
TABLE 1 - Patients characterization in bariatric surgery pre and post-operation in ambulatory assistance

\begin{tabular}{|c|c|c|}
\hline & $\mathrm{n}$ & $\%$ \\
\hline \multicolumn{3}{|l|}{ Gender } \\
\hline Women & 34 & 72,0 \\
\hline \multicolumn{3}{|l|}{ Age (years) } \\
\hline $20-39$ & 18 & 36,0 \\
\hline $40-59$ & 27 & 57,0 \\
\hline$\geq 60$ & 2 & 4,0 \\
\hline \multicolumn{3}{|l|}{ Nutritional state at admission } \\
\hline Eutrophic & 0 & 0,0 \\
\hline Over weight & 0 & 0,0 \\
\hline Obesity grade I & 0 & 0,0 \\
\hline Obesity grade II & 0 & 0,0 \\
\hline Obesity grade III & 47 & 100,0 \\
\hline \multicolumn{3}{|l|}{ Nutritional state at surgery } \\
\hline Eutrophic & 0 & 0,0 \\
\hline Over weight & 0 & 0,0 \\
\hline Obesity grade I & 1 & 2,1 \\
\hline Obesity grade II & 8 & 17,0 \\
\hline Obesity grade III & 38 & 80,9 \\
\hline \multicolumn{3}{|l|}{ Nutritional state post-operation } \\
\hline Eutrophic & 1 & 2,6 \\
\hline Over weight & 3 & 7,9 \\
\hline Obesity grade I & 11 & 28,9 \\
\hline Obesity grade II & 10 & 26,3 \\
\hline \multirow[t]{2}{*}{ Obesity grade IIIa } & 13 & 34,2 \\
\hline & $x$ & DP \\
\hline Age & 43,6 & $\pm 9,8$ \\
\hline Admission age & 141,5 & $\pm 27,0$ \\
\hline Surgery Age & 132,6 & $\pm 27,0$ \\
\hline Post- operation agea & 101,9 & $\pm 23,3$ \\
\hline Admission BMI & 53,5 & $\pm 8,8$ \\
\hline Surgery BMI & 50,1 & $\pm 9,2$ \\
\hline Post-operation BMIa & 38,6 & $\pm 8,2$ \\
\hline Nutritional assistance time (years)a & 2,6 & $\pm 2,0$ \\
\hline Pre-operation time (years) & 1,7 & $\pm 1,8$ \\
\hline Post-operation time (years)a & 0,8 & $\pm 0,7$ \\
\hline
\end{tabular}

BMI: Body mass index; $\mathrm{n}$ : absolute frequency, \%: relative frequency, $\mathrm{X}$ : medium;

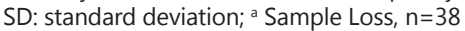

Table 2, shows a significant reduction on average score of all co-morbidities related to obesity, CMR components, since admission up to 12 months after. The average score was, sensibly, higher for arterial hypertension, showing at admission a total of $80.9 \%$ patients in medication treatment or presenting complication, showing a considerable reduction at 3 , 6 and 12 months post-operation. These findings were also expressed for the remaining $C M R$, dyslipidemia and diabetes mellitus type 2 components.

Table 3 shows the clinical evolution of the CMR components during nutritional assistance pre and postoperation and total. It was possible to evaluate that all co-morbidities evaluated, independent of nutritional assistance at the moment, the patients amount, that had them reverted overcame the one that had them just enhanced. Related to reverted co-morbidities, except one case of dyslipidemia, reverted still in preoperatory, all were reverted in post-operation or total assistance. It is important to note that the higher the level of complications the longer it took for reversing the pathology, once that the patients that evolved from score 3 to 0 was higher in post-operation nutritional assistance, while that evolved from score 4 to 0 , made necessary a higher intervention time, being the evolution, predominantly, in total assistance, therefore, since admission, involving pre and postoperation assistance. The reversion since the moment of highest complication, of the score from 5 to 0 , was possible only for one diabetes mellitus case. The treatment medication abolition for mellitus diabetes and dislipidemia, was possible still at pre-operation in $2.1 \%$ and $4.2 \%$ of the cases respectively.

TABLE 2 - Co-morbidities assessment scores related to obesity (AORC), according to different nutritional assistance moments

\begin{tabular}{|c|c|c|c|c|c|}
\hline AORC score & Admission & Surgery & $\mathrm{PO} 3$ & PO6 & PO12 \\
\hline \multicolumn{6}{|l|}{ Diabetes mellitus } \\
\hline Average score & $0,8 \pm 1,3$ & $0,6 \pm 1,2^{*}$ & $0 \pm 0^{* *}$ & $0 \pm 0^{* *}$ & $0 \pm 0^{* *}$ \\
\hline$\leq 2$ & $37(78,7)$ & $38(80,9)$ & $47(100)$ & $43(100)^{a}$ & $37(100)^{b}$ \\
\hline$\geq 3$ & $10(2]$ & $9(1$ & 0 & 0 & 0 \\
\hline \multicolumn{6}{|l|}{ Dyslipidemia } \\
\hline Average score & $2,1 \pm 1,6$ & $1,8 \pm 1,6^{*}$ & $0,1 \pm 0,4^{* *}$ & $0 \pm 0^{* *}$ & $0 \pm 0^{* *}$ \\
\hline$\leq 2$ & $18(38,3)$ & $20(42,6)$ & $46(97,9)$ & $43(100) a$ & $37(100) b$ \\
\hline$\geq 3$ & $29(61,7)$ & $27(57,4)$ & $1(2,1)$ & $0^{\mathrm{a}}$ & $0^{b}$ \\
\hline \multicolumn{6}{|l|}{ Hypertension } \\
\hline Average score & $3 \pm 1,4$ & $2,6 \pm 1,3^{*}$ & $0,4 \pm 0,9 * *$ & $0,1 \pm 0,4^{* *}$ & $0,1 \pm 0,5^{\star *}$ \\
\hline$\leq 2$ & $9(19,1)$ & $9(19,1)$ & $42(89,4)$ & $42(97,7)^{a}$ & $36(97,3)^{b}$ \\
\hline$\geq 3$ & $38(80,9)$ & $38(80,9)$ & $4(8,5)$ & $1(2,3)^{\mathrm{a}}$ & $1(2,7)^{b}$ \\
\hline Cardio metabolic risks & $8(17)$ & $8(17)$ & 0 & $\mathrm{Oa}$ & $0^{\mathrm{b}}$ \\
\hline \multicolumn{6}{|c|}{$\begin{array}{l}\text { AORC score } \leq 2 \text { : patients in non-medication treatment; } A O R C \text { score } \geq 3 \text { : patients } \\
\text { in medication treatment or presenting complications; cardiometabolic risks: } \\
\text { AORC score } \geq 3 \text { for all three co-morbidities: diabetes mellitus, dyslipidemia and } \\
\text { hypertension; PO3: post-operation at three months, nearly; PO6: post-operation } \\
\text { at six months, nearly; PO12: post-operation at } 12 \text { months, nearly. Average data } \\
\text { and standard deviation }[X \pm S D] \text { or absolute and relative frequency [n (\%)]. } \\
a, b \text { Sample loss, }{ }^{a} n=43,{ }^{b} n=37 ;{ }^{*} p<0,05 ; W \text { Wilcoxon surgery test relating to } \\
\text { admission; }{ }^{* \star} p<0,05 ; \text { W Wilcoxon surgery test relating to post-operation. }\end{array}$} \\
\hline
\end{tabular}

\section{DISCUSSION}

In studies carried out in Brazil with bariatric patients, it was not still evidenced a method and/ or instrument that can quantify the benefits of the surgery for the health of these patients. The AORC consists of a standardized and easy use method, proposing the evaluation of patients submitted to bariatric surgery, because the use of this instrument expresses in a quantitative form the clinical evaluation of the surgical treatment of obesity ${ }^{11}$.

On most studies, the co-morbidities control is presented in a qualitative form. In the present study the control referred was quantified, as proposed by Mohamed et al (2009) ${ }^{11}$. After applying AORC a clinical evolution was observed marked by the significant reduction of average score of co-morbidities related to obesity (diabetes mellitus, arterial hypertension, dislipidemia), from the obesity surgical treatment, as of the pre-operation conventional treatment. 
TABLE 3 - Cardiometabolic risk component evolution in patients submitted to bariatric surgery, according to different nutritional assistance

\begin{tabular}{|c|c|c|c|c|c|c|c|c|c|}
\hline \multirow[t]{2}{*}{ Score evolution AORC } & \multicolumn{3}{|c|}{ Diabetes } & \multicolumn{3}{|c|}{ Dyslipidemia } & \multicolumn{3}{|c|}{ Arterial hipertension } \\
\hline & $1^{\circ}$ & $2^{\circ}$ & $3^{\circ}$ & $1^{\circ}$ & $2^{\circ}$ & $3^{\circ}$ & $1^{\circ}$ & $2^{\circ}$ & $3^{\circ}$ \\
\hline \multicolumn{10}{|l|}{ Reverse co-morbidity } \\
\hline $3 \rightarrow 0$ & 0 & $8(17,4)^{a}$ & $7(15,2)^{a}$ & $1(2,1)$ & $22(47,8)^{a}$ & $16(36,4)^{b}$ & 0 & $27(62,8)^{c}$ & $14(29,8)$ \\
\hline $4 \rightarrow 0$ & 0 & 0 & 0 & 0 & $2(4,4) d$ & $10(21,3)$ & 0 & $6(12,8)$ & $19(44,2)^{c}$ \\
\hline $5 \rightarrow 0$ & 0 & 0 & $1(2,1)$ & 0 & 0 & 0 & 0 & 0 & 0 \\
\hline \multicolumn{10}{|l|}{ Enhanced co-morbidity } \\
\hline $3 \rightarrow 1$ & $1(2,1)$ & $0^{\mathrm{a}}$ & $0^{\mathrm{a}}$ & $1(2,1)$ & $0^{a}$ & $0^{\mathrm{b}}$ & 0 & $0^{c}$ & 0 \\
\hline $3 \rightarrow 2$ & 0 & $0^{\mathrm{a}}$ & $0^{\mathrm{a}}$ & 0 & $0^{\mathrm{a}}$ & $0^{\mathrm{b}}$ & 0 & $0^{c}$ & 0 \\
\hline $4 \rightarrow 1$ & 0 & 0 & 0 & $0^{d}$ & 0 & 0 & 0 & 0 & $0^{c}$ \\
\hline $4 \rightarrow 2$ & 0 & 0 & 0 & 0 & $0^{d}$ & 0 & 0 & 0 & $0^{c}$ \\
\hline $4 \rightarrow 3$ & 0 & 0 & 0 & $9(19,1)$ & $0^{d}$ & 0 & $20(42,6)$ & 0 & $1(2,3)^{c}$ \\
\hline $5 \rightarrow 1$ & 0 & 0 & 0 & 0 & 0 & 0 & 0 & 0 & 0 \\
\hline $5 \rightarrow 2$ & 0 & 0 & 0 & 0 & 0 & 0 & 0 & 0 & 0 \\
\hline $5 \rightarrow 3$ & $1(2,1)$ & 0 & 0 & 0 & 0 & 0 & 0 & 0 & 0 \\
\hline $5 \rightarrow 4$ & 0 & 0 & 0 & 0 & 0 & 0 & 0 & 0 & 0 \\
\hline Medication treatment reversed & $1(2,1)$ & $8(17,4)$ & $8(17,3)$ & $2(4,2)$ & $24(43,4)$ & $26(57,7)$ & 0 & $33(75,6)$ & $33(74)$ \\
\hline No medication & 0 & 0 & 0 & 7 & 0 & 0 & 0 & 13 & 32 \\
\hline
\end{tabular}

A higher nutritional assistance time before bariatric surgery, can contribute for co-morbidities control associated to disease, mainly, arterial hypertension, through the adoption of a new food habit and regular physical activity practice, being the patient capable of presenting, still in a pre-surgical period, important clinical enhancements associated to $\mathrm{CMR}^{6}$.

Previous studies show enhancement in several clinical manifestations of CMR being controlled or reduced in almost totality 3, 5, 9, 10. However, especially in case of diabetes, this enhancement can be attributed to weight loss and better resistance to insulin, since, the evolution of the same is observed almost immediately after surgical procedure ${ }^{12}$.

Besides gastric reduction and duodenal derivation that directly help weight loss, enhancement or reversion of diabetes type 2, after surgery is due, mainly, for anatomic and hormonal alterations from the gastrojejunal derivation. Due to anatomic approximation between the stomach and the ileum, the food will reach the distal intestine earlier and, as consequence, a higher production of incretin GLP - 1 and GIP, besides the production of ghrelin. Once they are liberated, the incretin act in the pancreas stimulating the production of insulin that will contribute with the glycemic control ${ }^{1,10,12,14}$. The ghrelin production reduction is provoked by the gastric end exclusion characterizing the sacietogen effect of this surgery ${ }^{4,12}$.

The reduction, or even the abolition of medication, after surgery treatment, as evidenced in this study is a condition, probably influenced by the long term sustainable weight loss, food habits improvement and regular physical activity practice, determined by surgery treatment of obesity, reflecting not only in socio-economical life of the patients, but, mainly, enhancing the life quality of these individuals ${ }^{4}$.

By AOCR it was possible to evidence the clinical evolution of the patients submitted to surgery treatment of obesity in our institution.

\section{CONCLUSION}

The Assessment of Obesity-Related Comorbidities is a system that can be effectively used to quantify the degree of reduction of the severity of the cardiometabolic risk in response to bariatric surgery.

\section{REFERENCES}

1. Ayoub JAS, Alonso PA, Guimarães LMV. Efeitos da Cirurgia Bariátrica sobre a Síndrome Metabólica. Arq Bras Cir Dig. 2011; 24 (1):14043.

2. Carvalho PS, Moreira CLCB, Barelli MC, Oliveira FH, Guzzo MF, Miguel GPS, Zandonade E. Cirurgia Bariátrica Cura Síndrome Metabólica. Arq Bras Endocrinol Metab. 2007; 51(1):79-85.

3. Desiderio J,Trastulli S, Scalercio V, Mirri E, Grandone I, Cirocchi R, Penzo J, Santoro A, Redler A, Boselli C, Noya G, Fatati G, Parisi A. Effects of laparoscopic sleeve gastrectomy in patients with morbid obesity and metabolic disorders. Diabetes Technol Ther, 2013; 15(12):1004-9.

4. Geloneze B, Pareja JC. Cirurgia Bariátrica Cura a Síndrome Metabólica? Arquivo Brasileiro de Endocrinologia e Metabolismo. 2006; 50(2):120-34.

5. Giusti V, Suter M, Héraïef E, Gaillard RC, Burckhardt P. Effects of laparoscopic gastric banding on body composition, metabolic profile and nutritional status of obese women: 12-months' followup. Obes Surg. 2004;14(2): 239-45.

6. Greenwald A. Current nutritional treatments of obesity. Adv Psychosom Med. 2006; 27:24-41.

7. Karmali S, Brar B, Shi X, Sharma AM, de Gara C, Birch DW. Weight recidivism post-bariatric surgery: a systematic review. Obes Surg. 2013; 23(11): 1922-33. 
8. Khawali C, Ferraz MB, Zanella MT, Ferreira SRG. Evaluation of quality of life in severely obese patients after bariatric surgery carried out in the public healthcare system. Arq Bras Endocrinol Metab. 2012; 56(1): 33-38.

9. Lee WJ. Effects of obesity surgery on the metabolic syndrome. Arch Surg. 2004; 139: 1088-92.

10. Madan AK, Orth W, Ternovits CA, Tichansky DS. Metabolic syndrome: yet another co-morbidity gastric bypass helps cure. Surg Obes Relat Dis. 2006; 2: 48-51.

11. Ali MR, Fuller WD, Rasmussen J. Detailed description of early response of metabolic syndrome after laparoscopic Roux-en-Y gastrc bypass. Surgery for Obesity and Related Diseases. 2009; 5: 346-51.
12. Monteiro FC, Silva WS, Filho NS, Ferreira PAM, Araújo GF, Mandarino NR, Barbosa JB, Lages JS, Lima JRO, Monteiro CC. Efeito da perda ponderal induzida pela cirurgia bariátrica sobre a prevalência de síndrome metabólica. Arq Bras Cardiol 2009; 92(6):452-456.

13. Reaven GM. Themetabolic syndrome: time to get off themerrygo-round? Journal of Internal Medicine. 2010; 269:127-136.

14. Weiner S, Neugehauer EA. Quality of life of diabetic patients with medical or surgical treatment. Nutr Hosp., 2013 2:66-77. 